\title{
Effects of light and temperature treatments on germination and physiological traits of Stevia seedling (Stevia rebuadiana Bertoni)
}

\author{
M. Aghighi Shahverdi ${ }^{1}$, H. Omidi ${ }^{1}$, H. Mosanaiey ${ }^{2}$, M. Pessarakli ${ }^{3 *}$, S. E. Mousavi ${ }^{1}$, M. \\ Ghasemzadeh $^{1}$ \\ ${ }^{1}$ Agricultural College and Medicinal Plant Research Center, Shahed University, Tehran, Iran \\ ${ }^{2}$ Department of Agronomy, Agriculture Faculty, Islamic Azad University of Gorgan branch, \\ Iran, \\ 3* Professor, School of Plant Science, University of Arizona, Tucson, AZ, 85721, USA \\ * Corresponding Author E-mail: pessarak@email.arizona.edu
}

\begin{abstract}
Light and temperature are among the environmental factors affecting germination of seeds and seedling growth. Therefore, this experiment was carried out to evaluate the effect of light (light, dark, and combined light and dark) and temperature (15, 20, 25, and $\left.30{ }^{\circ} \mathrm{C}\right)$ treatments on seed germination indices and physiological traits of stevia. With increasing temperature to $25^{\circ} \mathrm{C}$, percentage and rate of germination, seedling length, and vigor index increased. Also, dark and integrated treatments light and dark conditions caused increased all traits, except for the mean germination time. The highest proline and protein contents were achieved under light conditions at 15 and $30^{\circ} \mathrm{C}$, respectively. With increasing temperature, the activity of antioxidant enzymes catalase and superoxide dismutase increased. The highest activities of catalase and superoxide dismutase were observed under light condition. In contrary, the highest peroxidase activity was observed under dark condition. Overall, the results showed that dark and combined dark and light conditions at $25{ }^{\circ} \mathrm{C}$ improved the physiological characteristics of the plant that can increase germination indices.
\end{abstract}


Keywords: Antioxidant activity, Cardinal temperatures, Proline, Protein, Seed vigor

\section{Introduction}

Stevia (Stevia rebaudiana Bertoni.), also known as a honey leaf, is a perennial plant belonging to the family Asteraceae and native to Paraguay (Pal et al., 2013). The plant has small white florets and average seed weight of $300 \mathrm{mg}$ (Abou-Arab et al., 2010). It is a source of glycosides de-terpenoids (4-20 percent) (Prakash et al., 2008). The plant has a sweet taste due to the presence of diterpene steviol glycosides (SV glys). Stevioside and Rebaudioside-A (Reb-A) are dominant glycoside compositions of the plant which make the plant to be even 300 times sweeter than sucrose (Hajihashemi and Ehsanpour, 2014), and it is useful for those who suffer diseases such as diabetes, heart disease, and tooth decay (Ghanta et al., 2007; Palazzo et al., 2011). Stevia extracts have been used commercially for sweet foods (sweeten foods) in Japan and other Southeast Asian countries for years (Kumar and Sharma, 2012).

Plant germination percentage is usually low, so large-scale cultivation of these plants is restricted (Kumar et al., 2010), and cultivation by sowing seed is also limited (Taware et al., 2010). Due to the self-incompatible flowers, polination is usually carried out by wind and insects (Raeeszadeh and Gharineh, 2014). Thus, the plant has low fertility percentage and hence low seed formation (Liopa-Tsakalidi et al., 2012) which limits its large-scale cultivation (Raji et al., 2015).

Different physiological factors (i.e., temperature) affect seed germination that varies for different seeds (Forcella et al., 2000). Seed germination is a complex process with many reactions at different stages that each of them is influenced by temperature. The effects of temperature on germination can be based on the cardinal temperatures, minimum, optimum 
(temperature at which the highest germination is achieved at shortest time), and maximum that the germination process occurs at these temperatures. Response to temperature depends on factors such as species, variety, region, seed quality, and duration of the harvest. The control of light mechanism in germination is similar to the control mechanism of the flower induction, stem elongation, and pigments in the leaf and fruit. The effect of light on seed germination has been known for a long time. Both light intensity and light quality (color or wavelength) affect germination (Akramghaderi et al., 2008).

The seed germination and seedlings grown in the dark indicate three specific modes of phytochrome action, which its property depends on different levels of radiation and reversible $\mathrm{R}$ / FR (Archin et al., 2013). Esra et al. (2016) reported effects of light and temperature were significant on stevia seed germination, and the highest percentage and rate of germination were in dark conditions at $25^{\circ} \mathrm{C}$ temperature. Researchers reported that the interaction of temperature and light treatments were significant on the seedling length of milkweed and increasing the temperature to $30{ }^{\circ} \mathrm{C}$ in light conditions caused increased seedling length (Khaef et al., 2012). In another study, the effect of light and temperature on seed germination of Black haloxylon was very significant on seedling length, while light had no effect on this trait (Ghaedi et al., 2009). The aim of this study was to evaluate germination indices and seedling physiological characteristics of stevia under different light and temperature treatments.

\section{Material and methods}

To study the effect of light and temperature on seed germination of Stevia rebaudiana Bertoni, a factorial experiment was conducted in a completely randomized design with 3 replications in Tehran Shahed University Laboratory of Seed Science and Technology. 
Experimental factors included different thermal treatments $\left(15,20,25\right.$, and $\left.30^{\circ} \mathrm{C}\right)$ and various light treatments (light, darkness, and the combination of light and darkness). Bertoni seeds varieties were provided by the Seed Production Company of the Medicinal Plants in FirouzabadFars, which were produced the previous year, and were disinfected for three minutes by sodium hypochlorite $10 \%$, then washed with distilled water. Then, in each petri dish, 50 seeds were placed on Whatman filter paper and $5 \mathrm{ml}$ of distilled water added to each petri dish. To prevent water from evaporating, Petri dish`s door was closed using parafilm. Seeds germination had been done in a controlled growth chamber with temperature and light based on the experimental treatments. Counting the germinated seeds was done on a daily basis from the second day and at the end of the 11th day, characteristics, germination percentage, germination rate, the average time of germination, seed`s length and vigor index were calculated according to the following equations.

Equation 1: Germination percentage: $\mathrm{GP}=(\mathrm{N} \times 100) / \mathrm{M}$

Equation 2: Germination rate: $\mathrm{GS}=\sum \mathrm{Ni} / \mathrm{Ti}$

Equation 3: Mean time germination: $\mathrm{GV}=\mathrm{GP} \times \mathrm{MDG}$

Equation 4: Seed vigor index: $\mathrm{SVI}=\mathrm{GP} \times$ Mean $(\mathrm{SL})$

where, $\mathrm{N}=$ sum of germinated seeds at the end of the experiment, $\mathrm{M}=$ total planted seeds, $\mathrm{Ti}=$ number of days after germination, $\mathrm{SL}=$ Seedling Length

The Bradford (1976) method was used to determine the total amount of soluble protein. The basis of this method is based on the color connection of Cumasi Blue-G250 in the acid reagent to the protein molecule. To measure the protein concentration, $20 \mathrm{ml}$ extracted distillate was diluted in 80 microliter extraction buffer and $5 \mathrm{ml}$ fresh blue berelinat reagent was added to it and stired for 2 minutes. Then, after 5 minutes, the absorption of radiation in $595 \mathrm{~nm}$ 
wavelength was read, and the amount of protein in the sample was calculated by using the standard curve made with Albumin serum.

The MacAdam et al. (1992) method was used for determination of peroxidase activity. The measurement was done based on the Guaiacol`s oxidation by this enzyme. To measure, 33 mmol of extracted distillate was mixed with $1 \mathrm{ml}$ peroxide, which included $12 \mathrm{~mm}$ Guaiacol, $5 \mathrm{~mm}$ hydrogen peroxide, and $50 \mathrm{~mm}$ potassium phosphate buffer $(\mathrm{pH}=7)$, and its absorption for 1 minute at intervals of 10 minutes was read. To make $100 \mathrm{ml}$ of potassium phosphate, $39 \mathrm{ml}$ of $50 \mathrm{mM}$ potassium phosphate monohydrate with $61 \mathrm{ml}$ of $50 \mathrm{mM}$ potassium diphosphate were combined. To obtain the amount of peroxidase and report it, the number of spectrophotometric readings was multiplied by 1000 and was divided by 26.6 , then, the result was multiplied by 2 .

To measure the concentration of catalase activity, the Dhindsa et al. (1981) was used. According to this method, $50 \mathrm{ml}$ of the extracted distillate was mixed with $1 \mathrm{ml}$ of catalase measurement solution which contained $50 \mathrm{mmol}$ of potassium phosphate buffer $(\mathrm{pH}=7)$ and $15 \mathrm{mmol}$ of hydrogen peroxide. Then the absorption at a wavelength of $240 \mathrm{~nm}$ for one minute was read by a spectrophotometer. To convert catalase, the number obtained from the spectrophotometer is multiplied by 1000 and divided by 39.2, then the result was multiplied by 2 .

The Beauchamp and Fridovich (1971) method was used to measure the activity of superoxide dismutase. This measurement is done based on the ability of superoxide dismutase to stop the photochemical restoration of stopnitroblue tetrazolium done by superoxide dismutase radicals in the presence of riboflavin in the light. In this method, $50 \mathrm{ml}$ of the extract was mixed with $1 \mathrm{ml}$ of superoxide dismutase measurement solution which contains $50 \mathrm{mM}$ of $75 \mathrm{mM}$ potassium phosphate $(\mathrm{pH}=7.8) \mathrm{NBT}, 13 \mathrm{mM}$ of $0.1 \mathrm{~m}$ L-methionine EDTA and $2 \mathrm{mM}$ riboflavin. To make the action happen, this mixture was placed in the light chamber for 15 minutes and then 
the resulting solution was put in the spectrophotometer and its optical density at the $560 \mathrm{~nm}$ wavelength will be read. To convert superoxide dismutase, the number from spectrophotometer was multiplied by 1000 and divided by 2 .

To measure the free protein content, the Bates et al. (1973) method was used. According to this method, $0.5 \mathrm{mg}$ leaf from each sample was placed in $10 \mathrm{ml} 3 \%$ sulfosalicylic acid aqueous solution and the resulting mixture was homogenized in a porcelain mortar with $2 \mathrm{ml}$ acetic acid added to each tube. Then, the samples were placed in a water bath at $100{ }^{\circ} \mathrm{C}$ for one hour and after removal from the bath were immediately placed in ice bath. Then, $4 \mathrm{ml}$ toluene were added to each test tube and mixed with an agitator for about 1-3 minutes to be completely uniform. The supernatant was used to determine the proline concentration using the proline standard curve in a spectrophotometer at the $520 \mathrm{~nm}$ wavelength.

\section{Statistical analysis}

Data analysis was performed using SAS 9.2 software and for the mean comparisons the LSD test was used at the 5\% probability level.

\section{Results and discussion}

\section{Germination indices}

The effect of temperature and light on germination percentage and rate, the average time of germination, plant length, seedling length, and vigor index were significant. Also, the only significant effect on the homogeneity of germination time was temperature (Table 1). The results of the mean comparisons showed that increasing the temperature from 15 to $20^{\circ} \mathrm{C}$, increased the percentage and the speed of germination and the highest germination speed was obtained at 25 ${ }^{\circ} \mathrm{C}$ (Table 2). The effect of light treatment on these characteristics showed that the highest amount was at the dark treatment which was not significantly different than the combination of 
light and dark treatment. The average changes in germination time under temperature treatment indicated that the highest amount was obtained at $30{ }^{\circ} \mathrm{C}$ (5.8 days) which was not significantly different from the $15{ }^{\circ} \mathrm{C}$ temperature treatment (Table 2). The effect of light treatment on this characteristic led to the highest amount obtained in light treatment (5.12 day) which was not significantly different from the combination of light and dark treatment. Increasing the temperature to $25{ }^{\circ} \mathrm{C}$ made the plant grow more with higher seed vigor index and the highest average of this characteristic was related to this temperature treatment. Light treatments caused the longest seedling to be found in the dark treatment $(1.12 \mathrm{~cm})$ which was not significantly different from the combination of light and dark treatment.

By increasing the temperature, the average length and vigor index increased and the highest amount was obtained at $25{ }^{\circ} \mathrm{C}$ which was significantly different from the rest of the treatments. The effect of light treatment showed that the highest amount of this characteristic was found in the dark treatment (69.55) and showed no significant difference with the combination of light and dark treatment. The results of the mean comparison showed that increasing temperature to $20^{\circ} \mathrm{C}$ caused the homogeneity of germination time in stevia seed and $20{ }^{\circ} \mathrm{C}$ temperature treatment did not show any significant difference compared with the temperature treatments afterwards which are 25 and $30^{\circ} \mathrm{C}$.

Temperature and light are the factors that have a direct or indirect effect on germination. The optimum temperature for germination of most seeds is between 5 to $30^{\circ} \mathrm{C}$ (Akramghaderi et al., 2008). Results of this experiment also showed that by increasing the temperature from 15 to $20{ }^{\circ} \mathrm{C}$, the required time for germination decreased and seeds germinated in a shorter time. According to the study carried out by Akramghaderi et al. (2008) to investigate the effects of temperature, it was concluded that by increasing the temperature from 10 to $40{ }^{\circ} \mathrm{C}$, time of 
complete germination decreased. Overall, the low temperature caused a significant delay on seed germination (Pourreza and Bahrani, 2012). Kumar and Sharma (2012) reported that stevia germination will be disturbed at low temperature, and sometimes also the high temperature has the same effect (Pourreza and Bahrani, 2012). In a research, Kawatani et al. (1976) reported that optimum temperature for Stevia's germination was $20{ }^{\circ} \mathrm{C}$, but in other reports, the best temperature was $25^{\circ} \mathrm{C}$ and darkness (Takahashi et al., 1996; Esra et al., 2016). In the research studying the effect of different temperatures in light and dark on germination on Cressa critical, the highest germination percent and rate was reported at $30{ }^{\circ} \mathrm{C}$ in both light and dark (Alavi et al., 2014). In the present research, the highest average germination was found between $15-20{ }^{\circ} \mathrm{C}$ in both dark and light. In other study, in which the effect of different temperatures on germination of Cramb kotschyana was investigated, it was shown that the highest amount of germination rate was at $2{ }^{\circ} \mathrm{C}$, and it kept decreasing by increasing the temperature and reached its lowest amount at $20{ }^{\circ} \mathrm{C}$, and after this temperature, it started to increase (Naghedinia and Rezvani-Moghadam, 2009). In a study that was done on the effect of light and temperature on germination of corn, the results showed that the effect of light on the stipes was statistically significant, but did not have any effect on the root length (Idicut, 2013).

\section{Physiological indices}

The effect of temperature and light treatments on physiological characteristics of proline content, the amount of protein, the activity of catalase, peroxidase, and superoxide dismutase were significant (Table 3). Also, the interactions of light and temperature on proline content and protein amount have a significant effect (Table 3). According to interaction comparison, the most amount of free proline was found in treatment composition of $15{ }^{\circ} \mathrm{C}$ at full brightness with 501.71 micromoles per gram (Figure 1). The amount of free proline in $25{ }^{\circ} \mathrm{C}$ had the lowest 
average value in comparison with other temperatures and in comparison of the three light conditions, light had the highest average value and the full dark had the lowest average for this characteristic (Figure 1).

The most amount of protein was found in treatment composition of $30{ }^{\circ} \mathrm{C}$ in full light with an average of 8.14 percent and the lowest average was in the treatment composition of 15 ${ }^{\circ} \mathrm{C}$ in darkness (Figure 2). By increasing temperature in all three light conditions, average protein value average will get more. The activity of catalase and superoxide dismutase had its highest amount at $15{ }^{\circ} \mathrm{C}$ and its lowest average value at $30{ }^{\circ} \mathrm{C}$ (Table 4). The highest activities of catalase and superoxide dismutase were observed in light and their lowest values were found in the dark. Increasing temperature to $25{ }^{\circ} \mathrm{C}$ caused a significant increase in the amount of peroxide, but more increase in temperature caused the average amount of peroxide to decrease, and most of the activity was found at $25{ }^{\circ} \mathrm{C}$ and the least was observed at $15{ }^{\circ} \mathrm{C}$ (Table 4). In comparison to the three conditions of light, absolute darkness had the most and absolute brightness had the least peroxide activity (Table 4).

Temperature and light are very important environmental factors and are determinative factors for germination and proper growth of the seed which are effective on morphological treats, photosynthetic capacity, some aspects of physiological and biochemical and the function of the plant (Dai et al., 2009). Most of the protection mechanisms of the inhibition of light consist of functions like changes in chlorophyll content, movement of chloroplasts, increase the capacity to inhibit reactive oxygen species (ROS) via increasing in the activity of the reactive enzymes or the concentration of the non-enzymatic antioxidants (Xiaohua et al., 2015). In the present research, catalase antioxidant enzyme activity and superoxide dismutase functions at low temperatures in comparison to the optimum and higher temperatures increased. Negative 
relations between the antioxidant activities and temperature have been reported by the researchers (Li et al., 2010; Ghasemzadeh et al., 2010; Boo et al., 2011). Antioxidants low activity at the higher temperatures may be the result of decrease in anthocyanin in the plants (He et al., 2010; Boo et al., 2011).

\section{References}

Abou-Arab, A.E., Abou-Arab, A.A. and Abu-Salem, M.F. 2010. Physiochemical assessment of natural sweeteners stevioside produced from Stevia rebaudiana Bertoni plant. African Journal of Food Science, 4: 269-281.

Akramghaderi, F., Soltani, A. and Sadeghipour, H.R. 2008. Cardinal temperature of germination in medical pumpkin (Cucurbita pepo conver pepo var. styriaca), borago (Borago officinalis L.) and black cumin (Nigella sativa L.). Asian Journal of Plant Science, 2: 101-109.

Alavi, S.H., Zand, A., Delkhosh, B., Qajar, F. and Alipur, H. 2014. Effects of temperature on seed germination indices of Cressa cretica in Rafsanjan pistachio producing regions. Journal of Iranian pistachios. 1(1): 57-49.

Archin, S., Rahimian Mashhad, H., Oveisi, M. and Tavakol-Afshari, R. 2013. Compare germination of two species of oxalis in response to light, wet soil conditions. Plant Protection (Agricultural Science and Technology), 27 (1): 117-111.

Bates, L., Waldren, R.P. and Teare, I.D. 1973. Rapid determination of free proline for water stress studies. Plant and Soil, 39:205-207.

Beauchamp, C. and Fridovich, I. 1971. Superoxide Dismutase: Improved assays and an assay applicable to acrylamide gels. Analytical Biochemistry, 44:276-287. 
Boo, H.O., Heo, B.G., Gorinstein, S. and Chon, S.U. 2011. Positive effects of temperature and growth conditions on enzymatic and antioxidant status in lettuce plants. Plant Science, 181:479-484.

Bradford, M.M. 1976. A rapid and sensitive method for quantitation of microgram quantities of protein utilizing the principle of protein-dye binding. Annual Review of Biochemistry, $72: 248-254$.

Dai, Y.J., Shen, Z.G., Liu, Y., Wang, L.L., Hannaway, D. and Lu, H.F. 2009. Effects of shade treatments on the photosynthetic capacity, chlorophyll fluorescence, and chlorophyll content of Tetrastigma hemsleyanum Diels et Gilg. Environmental Experimental Botany 65: 77-182. doi: 10.1016/j.envexpbot.2008.12.008

Dhindsa, R.H., Plumb-Dhindsa, R., and Thorpe, T.A. 1981. Leaf senescence correlated with increased level of membrane permeability, lipid peroxidation and decreased the level of SOD and CAT. Journal of Experimental Botany, 32: 93-101.

Esra, U., Yasar, O. and Kenan, T. 2016. The effects of light and temperature on germination of Stevia (Stevia rebaudiana Bertoni) Seeds. Turkiye Tarimsal Arastirmalar Dergisi, 3:3740.

Forcella, F., Benech-Arnold, R.L., Sanchez, R. and Ghersa, C.M. 2000. Modeling seedling emergence. Field Crops Research, 67: 123-139.

Ghaedi, M., Taghvaei, M., Falah Shamsi, Q.R. and Niyazi, A. 2009. The interactive effect of light, temperature and salinity on seed germination of black Haloxylon (Haloxylon aphyllum L.). Rangeland Journal, 2:411-420.

Ghasemzadeh, A., Jaafar, H.Z.E., Rahmat, S., Wahab, P.E.M. and Halim, M.R.A. 2010. Effect of 
different light intensities on total phenolics and flavonoids synthesis and antioxidant activities in young ginger varieties (Zingiber officinale Roscoe). International Journal of Molecular Science, 11:3885-3897.

Hajihashemi, S. and Ehsanpour, A.A. 2014. Antioxidant response of Stevia rebaudiana B. to Polyethylene Glycol and Paclobutrazol treatments under In vitro culture. Applied Biochemistry and Biotechnology, 172(8):4038-4052.

He, F., Mu, L., Yan, G.L., Liang, N.N., Pan, Q.H .Wang, J., Reeves, M.J. and Duan, C. Q. 2010. Biosynthesis of anthocyanins and their regulation in colored grapes. Molecules, 15: 9057-9091.

Idicut, L. 2013. The effect of light, temperature, and salinity on seed germination of three maize forms. Greener Journal of Agricultural Sciences, 3(4): 246-253.

Kawatani, T., Kaneki, Y. and Tanabe, T. 1976. The cultivation of stevia (Stevia rebaudiana). II Seed germination with particular reference to the optimum temperature and light sensitivity. Japanese Journal of Tropical Agriculture, 20(3): 137-142.

Khaef, N., Taghvaei, M., Sadeghi, H. and Niyazi, A. 2012. Analyze the effects of light and temperature on seed germination milkweed (Asclepias syriaca L.). Journal of Pasture, 5(1): 26-19.

Kumar, R. and Sharma, S. 2012. Effect of light and temperature on seed germination of important medicinal and aromatic plants in northwestern Himalayas. International Journal of Medicinal and Aromatic Plants, 2(3): 468-475.

Kumar, P.S., Mishra, D., Ghosh, G. and Panda, C.S. 2010. Medicinal uses and pharmacological properties of Moringa oleifera. International Journal of Phytomedicine, 2: 210-216.

Pal, P.K., Prasad, R. and Pathania, V. 2013. Effect of decapitation and nutrient applications on 
shoot branching, yield, and accumulation of secondary metabolites in leaves of Stevia rebaudiana Bertoni. Journal of Plant Physiology, 170:1526-35.

Li, Z., Zhao, X., Sandhu, A.K. and Gu, L. 2010. Effects of exogenous abscisic acid on yield, antioxidant capacities, and phytochemical contents of greenhouse grown lettuces. Journal of Agriculture and Food Chemistry, 58:6503-6509.

Liopa-Tsakalidi, A., Kaspiris, G., Salahas, G. and Barouchas, P. 2012. Effect of salicylic acid (SA) and gibberellic acid (GA1) pre-soaking on seed germination of stevia (Stevia rebaudiana) under salt stress. Journal of Medicinal Plants Research, 6: 416-423.

Mac-Adam, J.W., Nelson, R. and Sharp, E. 1992. Peroxidase activity in the leaf elongation zone of tall fescue. Plant Physiology, 99:872-878.

Naghedinia, N. and Rezvan-Moghaddam, C. 2009. Evaluation of temperature minimum, optimum and maximum germination Crumb. Iranian Journal of Field Crops Research, 7(2): 456-451

Palazzo, A.B., Carvalho, M.A.R., Efraim, P. and Bolini, H.M.A. 2011. Determination of sweetness concentration of sucralose, rebaudioside, and neotame as sucrose substitutes in new diet chocolate formulations using the time-intensity analysis. Journal of Sensory Studies, 26: 291-297.

Pourreza, J. and Bahrani, A. 2012. Estimating cardinal temperatures of milk thistle (Sylibum marianum) seed germination. American-Eurasian Journal of Agricultural \& Environmental Sciences, 12(11): 1485-1489.

Prakash, I., DuBois, G.E., Clos, J.F., Wilkens, K.L. and Fosdick, L.E. 2008. Development of stevia, a natural, non-caloric sweetener. Food and Chemical Toxicology, 46: 75-82.

Raeeszadeh, M. and Gharineh, M H. 2014. Effects of gibberellic acid, nitric acid and moist 
chilling on seed germination Stevia. First International Congress of the Plant Breeding and Seed Science and Technology, Tehran 4 to 6 September 2014.

Raji, A.A., Mohammad, B.O. and Zarina, B.Z. 2015. Acclimatized apparatus enhanced seed germination in Stevia rebaudiana Bertoni. International Journal of Biology, 7:28-34.

Takahashi, L., Melges, E., and Carneiro, J.W.P. 1996. Germination performance of seeds of Stevia rebaudiana (Bertoni.) under different temperatures. Revista Brasileira de Sementes, 18(1): 6-9.

Taware, A.S., Harke, S.N., Mukadam, D.S., Chavan, A.M. and Taware, S.D. 2010. Effect of different extracts of callus and plantlets of Stevia rebaudiana (Bertoni) on seed germination of some agricultural crops. African Journal of Biotechnology, 9(40): 66756683.

Xiaohua, M., Lili, S., Weiwu, Y., Yuanyuan, H., Yang, L., Jiasheng, W. and Yeqing, Y. 2015. Growth, physiological, and biochemical responses of Camptotheca acuminata seedlings to different light environments. Frontiers in Plant Science, 6:1-12. 
Table 1. Analysis of variance of the effects of temperature and different light conditions on germination indices of stevia seeds.

\begin{tabular}{|c|c|c|c|c|c|c|c|}
\hline \multirow[b]{2}{*}{ Source of variation } & \multirow[b]{2}{*}{$\mathrm{df}$} & \multicolumn{6}{|c|}{ Mean squares } \\
\hline & & $\begin{array}{l}\text { Germination } \\
\text { Percentage }\end{array}$ & $\begin{array}{l}\text { Germination } \\
\text { Rate }\end{array}$ & $\begin{array}{c}\text { Mean } \\
\text { Germination } \\
\text { Time }\end{array}$ & $\begin{array}{l}\text { Seedling } \\
\text { length }\end{array}$ & Vigor index & $\begin{array}{c}\text { Germination } \\
\text { Uniformity }\end{array}$ \\
\hline Temperature & 3 & $1190.43^{* *}$ & $8.65^{* *}$ & $0.27^{*}$ & $1.79^{* *}$ & $11019.23^{* *}$ & $2.88^{* *}$ \\
\hline Light & 2 & $96.60^{*}$ & $1.00^{* *}$ & $0.20^{*}$ & $0.08^{* *}$ & $657.15^{* *}$ & $0.13^{\mathrm{ns}}$ \\
\hline Temperature $\times$ Light & 6 & $6.48^{\mathrm{ns}}$ & $0.12^{\mathrm{ns}}$ & $0.08^{\mathrm{ns}}$ & $0.006^{\mathrm{ns}}$ & 22.39 ns & $0.03^{\mathrm{ns}}$ \\
\hline Error & 24 & 26.23 & 0.15 & 0.06 & 0.007 & 48.80 & 0.13 \\
\hline Coefficient of variation (\%) & - & 9.05 & 10.05 & 5.06 & 8.07 & 11.01 & 7.93 \\
\hline
\end{tabular}

ns, $*$, and $* * ;$ non-significant, significant at $5 \%$, and $1 \%$ probability levels, respectively.

Table 2. Mean comparison of the effects of temperature and light on germination indices of stevia medicinal plant seeds.

\begin{tabular}{ccccccc}
\hline $\begin{array}{c}\text { Different levels of } \\
\text { temperature }(\mathrm{C})\end{array}$ & $\begin{array}{c}\text { Germination } \\
\text { Percentage } \\
(\%)\end{array}$ & $\begin{array}{c}\text { Germination } \\
\text { Rate } \\
\text { (seed per } \\
\text { day) }\end{array}$ & $\begin{array}{c}\text { Mean } \\
\text { Germination } \\
\text { Time }(\text { day })\end{array}$ & $\begin{array}{c}\text { Seedling } \\
\text { length } \\
(\mathrm{cm})\end{array}$ & $\begin{array}{c}\text { Vigor } \\
\text { index }\end{array}$ & $\begin{array}{c}\text { Germination } \\
\text { Uniformity }\end{array}$ \\
\hline 15 & $40.74 \mathrm{c}$ & $2.63 \mathrm{c}$ & $5.16 \mathrm{ab}$ & $0.47 \mathrm{~d}$ & $19.70 \mathrm{~d}$ & $3.86 \mathrm{~b}$ \\
20 & $56.66 \mathrm{~b}$ & $4.10 \mathrm{~b}$ & $4.92 \mathrm{bc}$ & $0.93 \mathrm{c}$ & $53.11 \mathrm{c}$ & $5.07 \mathrm{a}$ \\
25 & $67.77 \mathrm{a}$ & $4.99 \mathrm{a}$ & $4.83 \mathrm{c}$ & $1.47 \mathrm{a}$ & $100.22 \mathrm{a}$ & $4.93 \mathrm{a}$ \\
30 & $61.11 \mathrm{~b}$ & $4.14 \mathrm{~b}$ & $5.18 \mathrm{a}$ & $1.32 \mathrm{~b}$ & $80.77 \mathrm{~b}$ & $4.96 \mathrm{a}$ \\
\hline Light condition & & & & & & \\
\hline lighting & $53.33 \mathrm{~b}$ & $3.65 \mathrm{~b}$ & $5.12 \mathrm{a}$ & $0.95 \mathrm{~b}$ & $55.22 \mathrm{~b}$ & - \\
darkness & $58.61 \mathrm{a}$ & $4.22 \mathrm{a}$ & $4.87 \mathrm{~b}$ & $1.12 \mathrm{a}$ & $69.55 \mathrm{a}$ & - \\
\hline Lighting/darkness & $57.77 \mathrm{a}$ & $4.02 \mathrm{a}$ & $5.08 \mathrm{ab}$ & $1.07 \mathrm{a}$ & $65.58 \mathrm{a}$ & - \\
\hline
\end{tabular}

Means followed by similar letters in the same column are not significantly different based on the LSD $(\mathrm{P}<0.05)$ test at 5\% probability level. 
Table 3. Analysis of variance of the effect of temperature and different light conditions on physiological indices of stevia seedlings.

\begin{tabular}{ccccccc}
\hline & & \multicolumn{5}{c}{ Mean squares } \\
\cline { 3 - 6 } Source of variation & df & $\begin{array}{c}\text { Proline } \\
\text { content }\end{array}$ & $\begin{array}{c}\text { Protein } \\
\text { content }\end{array}$ & $\begin{array}{c}\text { Catalase } \\
\text { activity }\end{array}$ & $\begin{array}{c}\text { Peroxidase } \\
\text { activity }\end{array}$ & $\begin{array}{c}\text { Superoxide } \\
\text { dismutase activity }\end{array}$ \\
\hline Temperature & 3 & $0.38^{* *}$ & $1.84^{* *}$ & $0.521^{* *}$ & $0.347^{* *}$ & $0.40^{* *}$ \\
Light & 2 & $0.41^{* *}$ & $1.02^{* *}$ & $0.283^{* *}$ & $0.12^{*}$ & $0.347^{* *}$ \\
Temperature $\times$ Light & 6 & $0.24^{* *}$ & $0.86^{* *}$ & $0.008^{\mathrm{ns}}$ & $0.06^{\mathrm{ns}}$ & $0.008^{\mathrm{ns}}$ \\
Error & 24 & 0.06 & 0.23 & 0.005 & 0.04 & 0.009 \\
\hline Coefficient of variation (\%) & - & 8.49 & 10.11 & 9.70 & 12.53 & 9.18 \\
\hline
\end{tabular}

. ns, ${ }^{*}$, and ${ }^{* *} ;$ non-significant, significant at $5 \%$ and $1 \%$ probability levels, respectively

Table 4. Mean comparison of the effect of temperature and light on physiological indices of stevia medicinal plant seeds.

\begin{tabular}{|c|c|c|c|}
\hline $\begin{array}{c}\text { Different levels of } \\
\text { temperature }(\mathrm{C})\end{array}$ & $\begin{array}{c}\text { Catalase } \\
\text { activity } \\
\left(\mu \mathrm{mol.min}{ }^{-1} . \mathrm{mg}\right. \\
\text { FW })\end{array}$ & $\begin{array}{c}\text { Peroxidase } \\
\text { activity } \\
\left(\mu \mathrm{mol}^{-\mathrm{min}^{-1}} \cdot \mathrm{mg}\right. \\
\text { FW })\end{array}$ & $\begin{array}{c}\text { Superoxide } \\
\text { dismutase activity } \\
\left(\mu \mathrm{mol} . \mathrm{min}^{-1} . \mathrm{mg}\right. \\
\text { FW })\end{array}$ \\
\hline 15 & $237.22 \mathrm{a}$ & $69.21 \mathrm{~d}$ & $357.04 \mathrm{a}$ \\
\hline 20 & $164.93 \mathrm{~b}$ & $139.03 \mathrm{c}$ & $280.11 \mathrm{~b}$ \\
\hline 25 & $158.14 \mathrm{~b}$ & $259.69 \mathrm{a}$ & $246.38 \mathrm{c}$ \\
\hline 30 & $106.10 \mathrm{c}$ & $185.14 \mathrm{~b}$ & $187.22 \mathrm{~d}$ \\
\hline \multicolumn{4}{|l|}{ Light condition } \\
\hline Lighting & $195.50 \mathrm{a}$ & $115.44 \mathrm{c}$ & $306.10 \mathrm{a}$ \\
\hline Darkness & $98.17 \mathrm{c}$ & $247.39 \mathrm{a}$ & $200.77 \mathrm{c}$ \\
\hline Lighting/ darkness & $153.31 \mathrm{~b}$ & $162.47 \mathrm{~b}$ & $261.59 \mathrm{~b}$ \\
\hline
\end{tabular}

Means followed by similar letters in the same column are not significantly different based on the LSD $(\mathrm{P}<0.05)$ test at $5 \%$ probability level. 


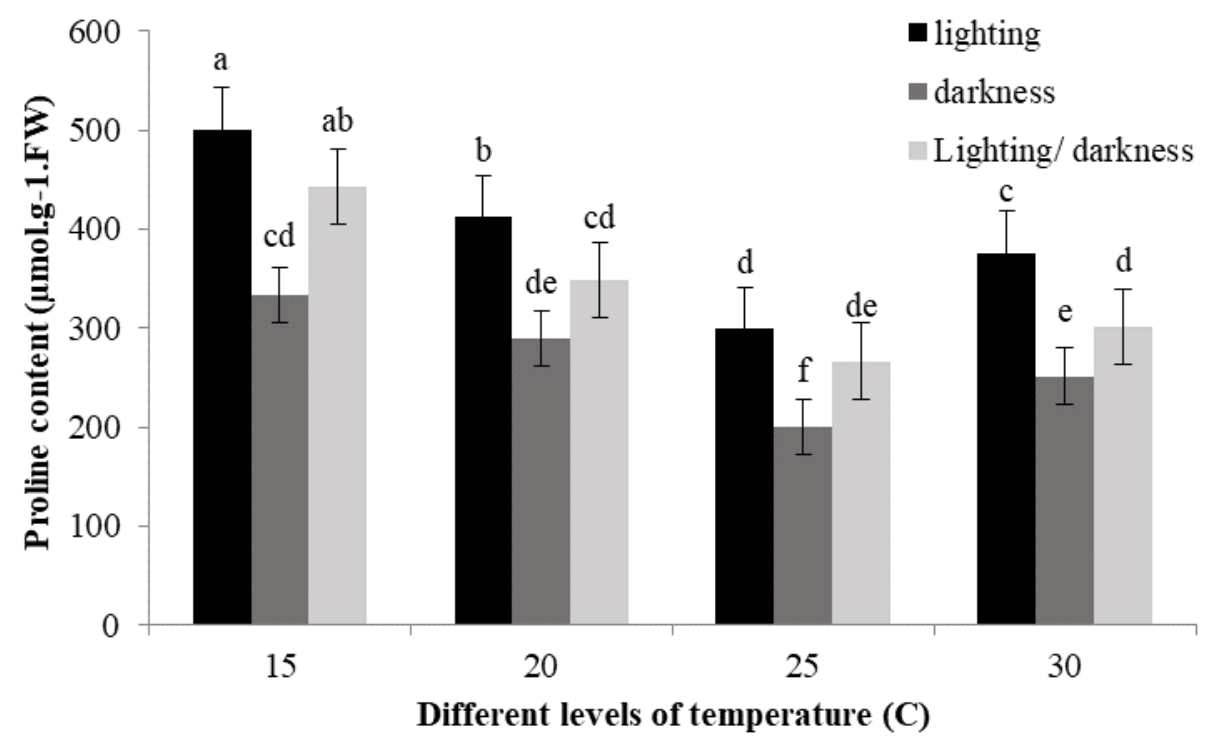

Figure 1. Comparison of the mean temperature and light treatments on proline content of Stevia seedlings.

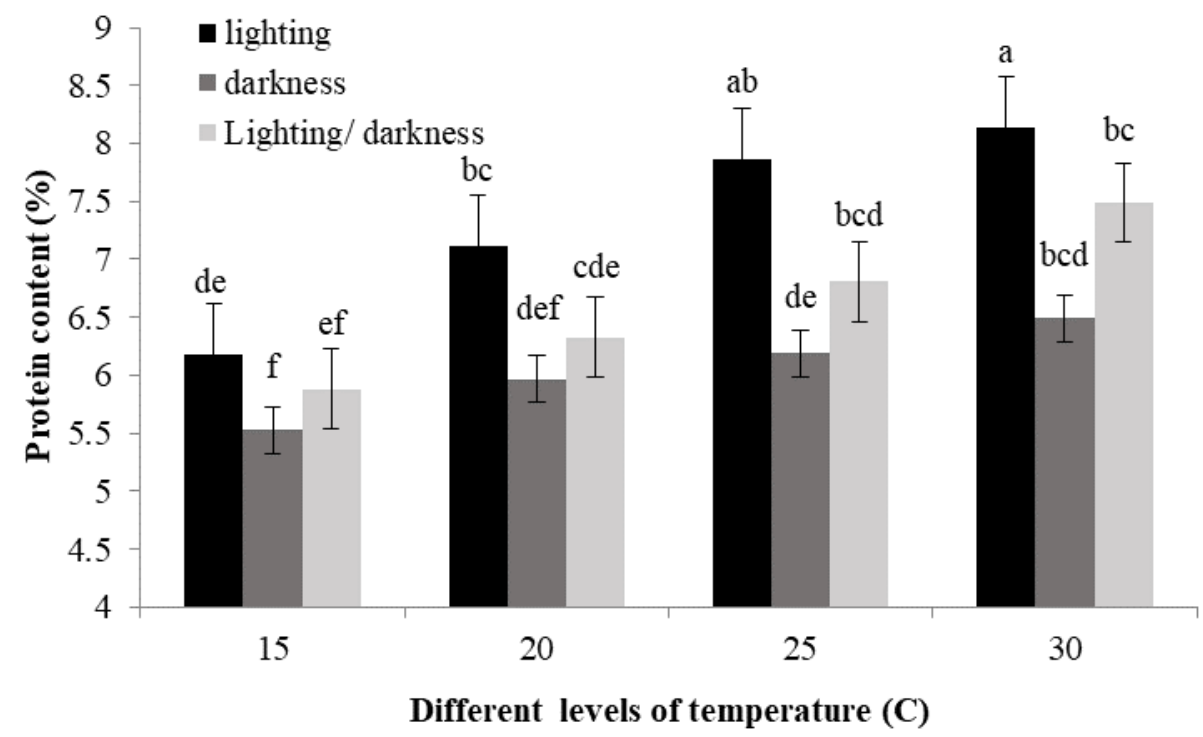

Figure 2. Comparison of the mean temperature and light treatments on protein content of Stevia seedlings. 